\title{
Altitudinal dependency of snow amounts in two small alpine catchments: can catchment-wide snow amounts be estimated via single snow or precipitation stations?
}

\author{
Thomas GRÜNEWALD, Michael LEHNING \\ WSL Institute for Snow and Avalanche Research SLF, Flüelastrasse 11, CH-7260 Davos-Dorf, Switzerland \\ E-mail: gruenewald@slf.ch
}

\begin{abstract}
The spatial distribution and the local amount of snow in mountainous regions strongly depend on the spatial characteristics of snowfall, snow deposition and snow redistribution. Uniform altitudinal gradients can only represent a part of these influences but are without alternative for use in larger-scale models. How well altitudinal gradients represent the true snow distribution has not been assessed. We analyse altitudinal characteristics of snow stored in two high-alpine catchments in Switzerland. Peak winter snow depths were monitored using high-resolution airborne laser scanning technology. These snow depths were transferred to snow water equivalent by applying simple density estimations. From these data, altitudinal gradients were calculated for the total catchment areas and for selected subareas characterized by different accumulation patterns. These gradients were then compared with gradients resulting from automated snow depth measurements obtained from several snow stations on different height levels located in the catchments, and with estimations from climatological precipitation gradients. The analysis showed that neither precipitation gradients nor flat-field stations estimate catchment-wide snow amounts accurately. While the climatological gradient showed different trends for different areas and years, the snow stations tended to overestimate mean snow amounts.
\end{abstract}

\section{INTRODUCTION}

Mountain snow cover is characterized by a high spatial heterogeneity. The amount of snow stored within an alpine catchment and its spatial distribution strongly influence avalanche risk, water storage or mountain ecology.

The spatial variability of the snow cover is governed by different processes which interact with the local topography. Precipitation-altitude relationships (e.g. Sevruk, 1997; Pipp and Locke, 1998; Wastl and Zängl, 2008) or preferential deposition of precipitation (Lehning and others, 2008; Mott and Lehning, 2010; Mott and others, 2010) result in spatial variable accumulation patterns of snow. Wind drift (e.g. Gauer, 2001; Liston and others, 2007; Lehning and others, 2008) or avalanches (e.g. Schweizer and others, 2003) further redistribute the snow. Another important effect is the altitude dependency of temperature, which affects the solid and liquid portions of precipitation.

Mountains strongly affect precipitation amounts. This effect usually accounts for an increase in precipitation with altitude (e.g. Lauscher, 1976; Lang, 1985; Kirchhofer and Sevruk, 1992; Zängl, 2008). Nevertheless, owing to the large effect of topography and climatology, precipitation gradients are known to vary on a regional scale (e.g. Sevruk, 1997; Schwarb and others, 2001; Wastl and Zängl, 2008). In general, similar gradients are found for mean and extreme precipitation events (Blanchet and others, 2009). Annual precipitation gradients, ranging from 0 to $200 \mathrm{~mm}$ per $100 \mathrm{~m}$ height difference have been published (e.g. Baumgartner and others, 1983; Schwarb and others, 2001). Baumgartner and others (1983) and Schwarb and others (2001) even report slightly negative gradients for some inner alpine regions.

As snow distribution is strongly affected by precipitation, the increase in precipitation is reflected in an increase in snow amounts with altitude as confirmed by several studies (e.g. Rohrer and others, 1994; Pipp and Locke, 1998; Foppa and others, 2005; López-Moreno and Stähli, 2008; Bavay and others, 2009; Bavera and DeMichele 2009; Jonas and others, 2009). From snow water equivalent (SWE) measurements, Keller and others (1984) found significant mean annual altitudinal gradients of SWE, ranging from 50 to $100 \mathrm{~mm}$ per $100 \mathrm{~m}$ elevation change which varied strongly over the years. Witmer (1986) reports similar results obtained from snow depth data.

However, all existing studies established altitudinal gradients on the basis of data obtained from a very limited number of meteorological stations or field surveys with point measurements. The aim of this study is to analyse highresolution snow depth observations to assess altitudinal gradients of the snow cover with respect to topographical and process-related deviations. Peak winter snow depths were collected using airborne laser scanning (ALS) technology for two high-alpine catchments located in eastern Switzerland. This allowed us not only to calculate robust mean altitudinal gradients of snow stored in the catchment but also to focus on different sub-areas, characterized by distinct topography and governed by different processes. We also examine the interannual persistence of the altitudinal gradients for one catchment by comparing data from two consecutive years. Additionally, meteorological stations located in and near the study areas permit a comparison with gradients obtained from these stations and those predicted by climatological altitudinal gradients.

\section{METHODS AND DATA}

\section{Site description}

We studied two small mountain catchments, located in the eastern part of the Swiss Alps (Fig. 1). The Wannengrat area (Fig. 1a) is near the city of Davos. The study area includes the Albertibach and Guggerbach basins, the Hintere Latschüel 


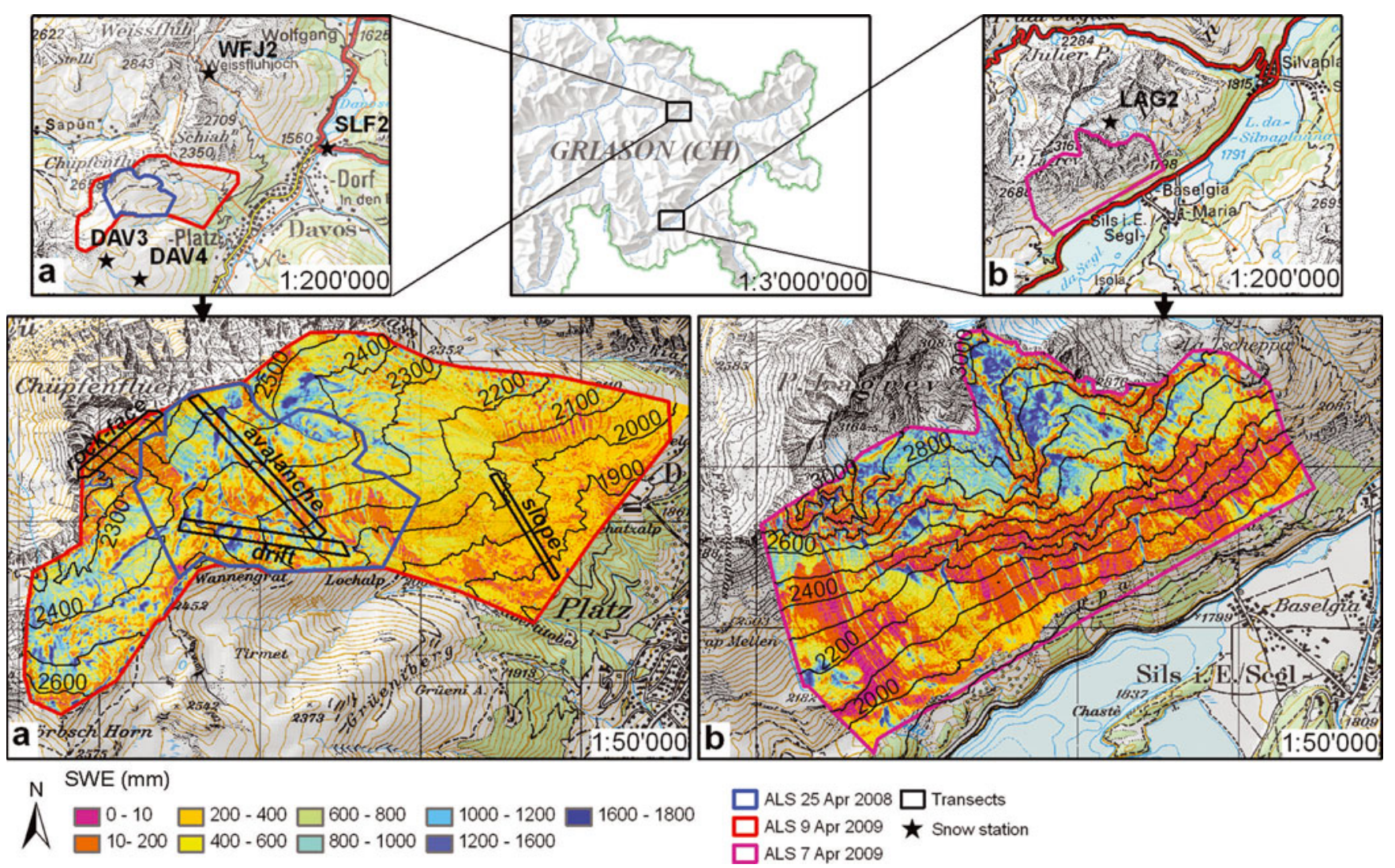

Fig. 1. Location of the Wannengrat (a) and Lagrev (b) test sites. The areas covered by ALS surveys are outlined with coloured lines, and flatfield snow stations are shown with black stars. The black lines show the sub-areas. SWEs shown in (a) and (b) refer to the 2009 ALS surveys. (Base map: Pixelkarte PK25 (C) 2009 swisstopo (dv033492).)

and the Chüpfenflue rock face. Elevations range from 1800 to $2658 \mathrm{~m}$ a.s.l. and are characterized by gentle slopes surrounded by steep mountain ridges.

The Lagrev area (Fig. 1b) includes the steep south-facing slopes of Piz Lagrev, which is located on the northern rim of the upper Engadin valley. Elevations range from 1800 to $3085 \mathrm{~m}$ a.s.I., and the site is characterized by steep slopes in the lower parts, followed by a band of rock faces and two pronounced bowls in the upper section. Each site has a total area of about $5 \mathrm{~km}^{2}$. A small part $\left(1.5 \mathrm{~km}^{2}\right)$ of the Wannengrat area was also monitored in 2008.

As one variant of the analysis, we defined several subareas, shown by the $50-75 \mathrm{~m}$ wide transect strips indicated in Figure $1 \mathrm{a}$. The sub-areas are characterized by distinct topography or by a dominant process which shapes the snow cover in the sub-area (i.e. drift, avalanche). The first sub-area (slope) is located on a gentle wind-protected slope just above the treeline. The second transect strip (avalanche) covers the southeast-facing slopes of the Albertibach catchment. This transect is characterized by a huge avalanche that was released at the upper slopes of Chüpfenflue in March 2009. No avalanche occurred in the 2007/08 season. Moreover we defined a sub-area which covers the northeastern slopes of Wannengrat (drift). This strip cuts two pronounced cornice-like drifts formed by wind (Grünewald and others, 2010; Mott and others, 2010; Schirmer and others, in press. The last sub-area selected for detailed analysis crosses the steep southeast-facing rock face of Chüpfenflue (rock face). Similar sub-areas were analysed for Lagrev but are not discussed in detail as they are based on the same processes and produced similar results.
The sites are equipped with meteorological stations, which provide continuous snow depth measurements (Fig. 1). For Wannengrat there are four stations: one in the valley and three at higher elevations up to $2540 \mathrm{ma}$ a.s.I. (Fig. 1a). For Lagrev, only one station is available, at 2730 ma.s.l. (Fig. 1b). For the valley floor, manual snow pole readings of two local avalanche observers are used.

\section{SNOW DEPTH MEASUREMENTS AND CALCULATION OF ALTITUDINAL GRADIENTS Areal snow depths obtained from ALS}

Area-wide snow depth measurements were obtained from three ALS campaigns using a helicopter-based technology (Vallet and Skaloud, 2005; Skaloud and others, 2006). ALS measures the distances from the scanner to the surface (snow cover) with high spatial resolution and accuracy. To obtain absolute snow depths, the scans must be subtracted from a digital elevation model. Digital elevation models were created in summer surveys for each study area using the same technology. The winter flights were operated on 26 April 2008 and 9 April 2009 for the Wannengrat area and on 7 April 2009 for Lagrev (Fig. 1). These dates are close to the time of peak accumulation and therefore represent most of the annual precipitation which fell as snow. For this interpretation, we need to neglect evaporation and occasional minor melt in our analysis.

The accuracy of the ALS was checked by comparing the data to a tachymeter survey which was performed simultaneously on the first flight across Wannengrat. The analysis showed that the difference between ALS and tachymeter data 
had a mean deviation of about $5 \mathrm{~cm}$ and a standard deviation of $6 \mathrm{~cm}$. More details on the accuracy of the ALS are provided by Grünewald and others (2010). No such quality checks could be performed for the two other datasets. Analysis of histogram representations of the snow depth distributions suggested that the data appear to be accurate for most areas with the exception of the rock faces at Lagrev. These areas showed very long-tailed distributions with a significant number of negative or extremely high snow depths. These unrealistic snow depths were excluded from the analysis.

Since precipitation and accumulation gradients are usually given in mmw.e., we had to transform the snow depth data to SWE. To achieve this, an estimation of the snow density is required. For this purpose we used the method of Jonas and others (2009), who provided a formula to directly calculate SWE from snow depth and the additional parameters: site altitude, site location and season.

Altitudinal gradients were calculated by dividing the study area into $100 \mathrm{~m}$ elevation bands. For each belt the mean SWE value and the standard deviation were determined. We calculated such gradients for the two overall sites and for each of the sub-areas defined above. We thus gained high-resolution altitude-SWE relationships as shown in Figure 2. Mean altitudinal gradients were calculated with linear regression analysis of altitude against SWE, giving $R^{2}$ values between 0.7 and 0.8 for the two study areas.

\section{Single-point snow depths obtained from snow stations}

To assess the quality of gradients obtained from single-point measurements, separate gradients were calculated from the snow stations located in the investigation areas (Fig. 1). The stations are part of the operational snow station network (International Measurement and Information System (IMIS)) operated by the Swiss avalanche warning service (Lehning and others, 1999). The flat-field snow stations are located at different altitudinal levels and provide automatic snow depth measurements. Since for Lagrev no automatic station was available at the valley floor, the average of two manual flat-field snow pole readings performed by two local avalanche observers in St Moritz (1890 m a.s.l.) and Maloja (1800 ma.s.l.) was used instead. SWE for each of the investigation dates was calculated from the snow depth measurements of the stations and observers applying the method described above. Altitudinal gradients were defined from the difference of SWE between the stations at different altitudes as indicated in Figure 2. Mean gradients were calculated using linear regression as described above.

\section{Climatological gradient (Hydrological atlas)}

For our analysis we chose a climatological gradient calculated from the annual precipitation gradient which was published in the Hydrological atlas of Switzerland (Kirchhofer and Sevruk, 1992). In this study an altitudinal gradient of $80 \mathrm{~mm}(100 \mathrm{~m})^{-1}$ was established to calculate a mean annual precipitation map of Switzerland. As this altitudinal gradient refers to an increase in precipitation relating to the total annual precipitation, the fraction of snow in the total amount of precipitation has to be taken into account. The solid portion of precipitation $\left(p p_{\text {snow }}\right)$ was calculated using precipitation and temperature data measured at gauged stations located in the two valley floors. To account for the increase in the portion of snow with altitude due to decreasing temperatures, the solid portion of precipitation should be calculated separately for each

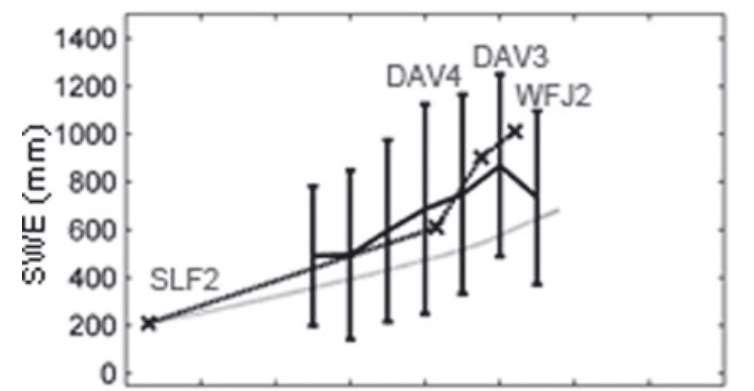

a 150017001900210023002500270029003100

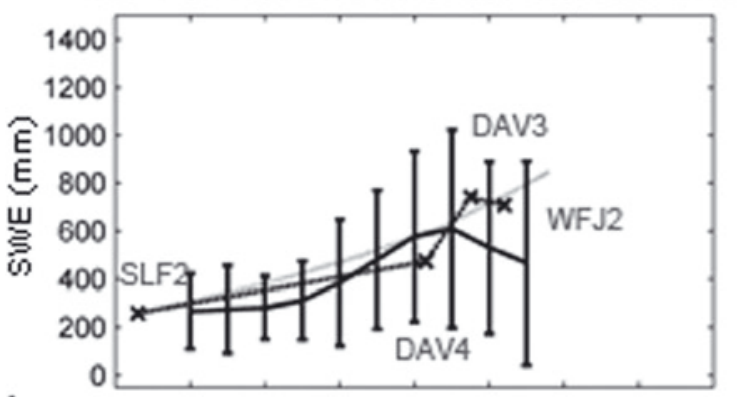

b 150017001900210023002500270029003100

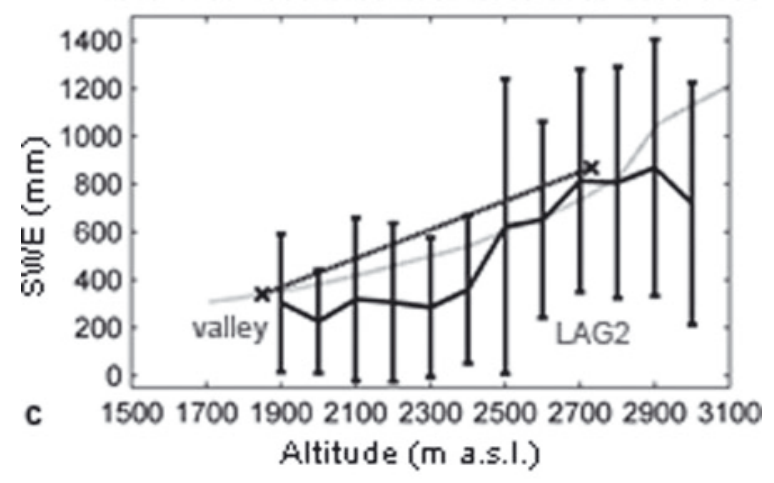

...*.... IMIS Hydrol. Atlas - ALS

Fig. 2. Altitudinal dependencies of SWE derived from IMIS flat-field snow stations, the Hydrological atlas of Switzerland and ALS data for (a,b) Wannengrat on (a) 26 April 2008 and (b) 9 April 2009 and (c) Lagrev on 7 April 2009. SWEs obtained from ALS were averaged to $100 \mathrm{~m}$ elevation bands. The $x$-axis label refers to the lower boundary of each band. The standard deviations from the ALS data are indicated by the black error bars. Locations of the snow stations are indicated by crosses and labelled with the station names.

elevation band $\left(p p_{\text {snow }}(h)\right)$. We thus determined temperature gradients between the valley stations and the mountain stations (WFJ2/LAG2) for each time-step. We then calculated the solid portion of precipitation for each band with the simplified assumption that precipitation at temperatures below $0^{\circ} \mathrm{C}$ falls as snow. Note that the gradient will not be very sensitive to the temperature threshold chosen to distinguish between liquid and solid precipitation. The formula for the gradient is

$$
\operatorname{SWE}(h)=S W E_{0}+\frac{80 \mathrm{~mm}}{100 \mathrm{~m}} p p_{\text {snow }}(h) \Delta h,
$$

where $\mathrm{SWE}_{0}$ is SWE at the snow station in the valley and $h$ is elevation (ma.s.I.). For the complete Wannengrat area, in $2007 / 0843 \%$ and in 2008/09 51\% of the annual precipitation was calculated to be snow. For Lagrev the portion was $59 \%$. Measurement accuracy of the gauges and effects of catch loss were not taken into account in these simplified calculations. 


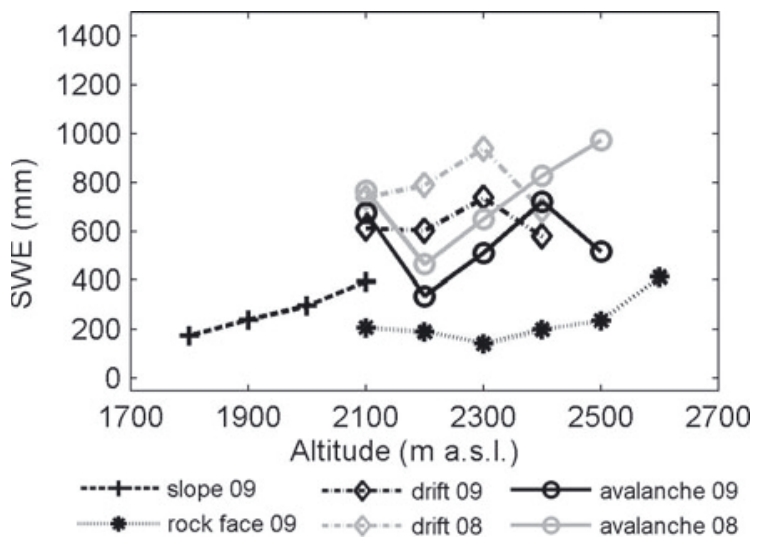

Fig. 3. Altitudinal dependencies of SWE for the sub-areas of Wannengrat indicated in Figure 1. Black lines refer to 9 April 2009 and grey lines to 26 April 2008.

\section{RESULTS AND DISCUSSION}

\section{Representativeness of 'simple' gradients and climatological gradients}

All altitudinal SWE gradients for the time of peak accumulation are shown in Figure $2 \mathrm{a}$ and $\mathrm{b}$ (Wannengrat) and Figure 2c (Lagrev). All curves show a distinct increase in SWE with altitude and thus confirm earlier findings (e.g. Keller and others, 1984; Witmer, 1986; Rohrer and others, 1994; Pipp and Locke, 1998). Nevertheless SWE does not increase linearly but is characterized by changing gradients for different elevation bands. Some segments even show negative gradients, which means that snow decreased with altitude for that section. These anomalies are attributed to the small-scale variability induced by topography and the snow redistribution, described in more detail below.

The climatological gradients show different trends. For the Wannengrat site, the climatological gradient greatly underestimates the measured altitudinal gradient of snow distribution in 2007/08 (Fig. 2a), but shows a small overestimation of the gradient in 2008/09 (Fig. 2b). For Lagrev, the climatological gradient is similar to the measured gradient (Fig. 2c).

This difference was confirmed by comparing mean gradients calculated from linear regression analysis. At Wannengrat the gradient interpreted from the Hydrological atlas was $42 \mathrm{~mm} \mathrm{SWE}(100 \mathrm{~m})^{-1}$ in $2007 / 08$ and $52 \mathrm{~mm}$ SWE $(100 \mathrm{~m})^{-1}$ in $2008 / 09$. From the ALS data, mean gradients of $58 \mathrm{~mm} \mathrm{SWE}(100 \mathrm{~m})^{-1}$ in $2007 / 08$ and $37 \mathrm{~mm}$ SWE $(100 \mathrm{~m})^{-1}$ in 2008/09 were obtained. At Lagrev a climatological gradient of $64 \mathrm{~mm} \mathrm{SWE}(100 \mathrm{~m})^{-1}$ versus a very similar measured gradient of $62 \mathrm{~mm}$ SWE $(100 \mathrm{~m})^{-1}$ was found. The spatial variability in the measured data, given by the error bars in Figure 2, was quite high for all elevations.

The gradients obtained from snow stations overestimate the real snow distribution. The station gradient for Wannengrat was too high in 2007/08 $\left(76 \mathrm{~mm} \mathrm{SWE}(100 \mathrm{~m})^{-1}\right)$ and 2008/09 $\left(46 \mathrm{~mm}\right.$ SWE $\left.(100 \mathrm{~m})^{-1}\right)$. For Lagrev, the station gradient $\left(60 \mathrm{~mm} \mathrm{SWE}(100 \mathrm{~m})^{-1}\right)$ was similar to the measured and climatological gradients.

There are strong deviations between SWE measured at flat-field stations and mean values calculated from the ALS data for the respective elevation bands. At Wannengrat, the flat-field station DAV3 was characterized by below elevation-band average SWE, whereas SWEs were much too high at DAV4 and WFJ2 for both years. The general overestimation can be explained by the fact that the flat-field measurements obtained at the stations do not represent the steep slopes and rock faces which characterize the topography at higher elevations of Wannengrat. In contrast, at Lagrev the highaltitude station LAG2 and the valley observations seem to reproduce the snow amount accurately.

\section{Influence of topography and processes}

Measured altitudinal gradients for selected sub-areas at Wannengrat are shown in Figure 3. The variation of the gradients reflects the different accumulation processes that characterize these sub-areas.

The slope sub-area is distinguished by a very regular gentle altitudinal gradient. The slope seems to be characterized by very homogeneous accumulation patterns which show a small but distinct effect of the altitude (Fig. 3). In contrast, the other three transects do not feature such regular gradients. The rock face shows a curve which first decreases and then increases slightly. This trend can be explained by the topography of the rock face. Flatter areas, where snow can accumulate, are located at the bottom and the top. Furthermore snow might have been redistributed by wind and avalanches from steeper to flatter sections.

A very distinct peak is obvious in the curve of the $d r i f t$ sub-area. This peak represents two large cornice-like drifts which developed owing to wind-induced redistribution of snow (Mott and others, 2010). The leeward side contributes to the higher snow amounts accumulated in this area. Both gradients for 2008 and 2009 show this distinct peak (Fig. 3).

A different pattern dominates the two curves for the avalanche sub-area for 2007/08 and 2008/09. Both curves are similar up to the $2400 \mathrm{~m}$ elevation band. Here a strong decrease was present in 2009 while the curve for 2008 still increased to $2500 \mathrm{~m}$. This difference demonstrates the effect of a large avalanche which occurred in March 2008 and which relocated most of the snow from the upper slopes. The accumulation area of the avalanche is not captured by the transect. The peak in the $2100 \mathrm{~m}$ elevation band is explained by a snow-filled ditch.

The local topography and the processes acting on the snow cover have a strong influence on the altitudinaldependent distribution of SWE. Previous studies demonstrated that the upper areas are dominated by wind-induced redistribution processes (Mott and others, 2010) whereas the lower parts of the investigation area are more sheltered, and redistribution of snow due to wind might therefore have a minor effect in these areas. A comparison of the slope and drift sub-areas reflects the spatially varying influence of the wind on snow accumulation (Fig. 3). Moreover, the relocation of snow by avalanches could be demonstrated in the avalanche transect and the influence of very steep and rough terrain by analysing the rock-face sub-area.

\section{Interannual persistence}

Even though only two sets of data were available for analysis, some observations on the interannual persistence (Schirmer and others, in press) of the snow distributions can be derived by analysing the Wannengrat data. Both curves (Fig. 2a and b) are characterized by a similar shape for elevations ranging up to $2400 \mathrm{~m}$. The absence of the pronounced peak in the $2500 \mathrm{~m}$ elevation band for 2009 is explained by the large avalanche that occurred in that season (see above). 
It is worth noting that SWE was much higher at all elevations in 2008. The 2007/08 winter was characterized by exceptionally high snow depths while the 2008/09 winter only showed average snow accumulation. Nevertheless, the total snow amount does not significantly influence the altitudinal gradient of the snow cover. This strong similarity of altitudinal gradients for both years confirms the findings of Schirmer and Lehning (in press) and Schirmer and others (in press), who studied snow-depth distributions and their scaling behaviour for three sub-areas at Wannengrat and found very strong interannual correlations.

\section{CONCLUSION}

A set of high-resolution SWE data obtained from ALS campaigns was used to analyse the altitudinal characteristics of the snow distribution at the time of peak accumulation. We investigated data from the two alpine catchments, Wannengrat and Lagrev. For Lagrev, only data from one ALS campaign were available whereas 2 years of observations were available for Wannengrat. Clear altitudinal gradients for SWE could be detected from the measurements. This confirms previous studies on altitudinal dependencies of snow and precipitation amounts.

A good interannual consistency of measured SWE altitudinal gradients was found, while total snow amounts were clearly different. This finding is in agreement with the studies of Mott and others (2010) and Schirmer and others (in press) who report a strong interannual correlation of the snow-depth distributions. However, investigating sub-areas we found a strong influence of the local topography and of local snow redistribution processes due to wind or avalanches. On small scales, these local effects clearly override the regional accumulation patterns.

From comparison with the climatological gradient published in the Hydrological atlas of Switzerland (Kirchhofer and Sevruk, 1992) we found that this gradient did not show a consistent relationship with the measured ALS gradients. For Wannengrat the climatological gradient underestimated snow amounts in 2007/08 but overestimated them in 2008/09. For Lagrev the gradient seemed to be a good estimation for the real snow distribution.

An investigation of altitudinal gradients obtained from flat-field snow stations located in the area indicated that these gradients tend to overestimate the snow-elevation dependency found in reality. This may be attributed to the fact that flat-field sites, which are usually used for snow stations, become biased towards 'more than average snow' at higher altitudes, where snow redistribution becomes more important. Furthermore, detailed analysis of specific elevation bands showed strong deviations from average snow amounts, depending on local characteristics of the terrain or on the occurrence of an avalanche.

Future work on altitudinal characteristics would strongly benefit from larger datasets. On the one hand, highresolution measurements of more study sites, spread over different regions, would be important to allow for general conclusions on regional deviation and characteristics. On the other hand, for a more accurate assessment of interannual persistence, a larger dataset covering several seasons would be required. One important aspect is whether the altitudinal gradient changes over the winter and for individual storms. This could not be addressed in the analysis presented here and would require repeated measurements at high temporal resolution over a winter. Finally, analysis of such area-wide datasets using more advanced methods like geostatistics or physically based model approaches (Lehning and others, 2008; Mott and Lehning, 2010) would provide more complete knowledge on spatial snow-cover distributions.

\section{ACKNOWLEDGEMENTS}

Thanks go to the 'Amt für Wald Graubünden', which partly financed the ALS flights. Part of the work has been funded by the Swiss National Science Foundation and the European Community. For providing precipitation data we acknowledge MeteoSwiss and C. Marty who prepared the data for the analysis. This work would not have been possible without all colleagues from SLF who contributed to the work in various ways. Finally we want to highlight the very constructive contributions of and discussions with our colleagues R. Mott and M. Schirmer and also thank two anonymous reviewers who helped to improve the paper considerably.

\section{REFERENCES}

Baumgartner, A., Reichel, E., and Weber, G. 1983. Der Wasserhaushalt der Alpen. Niederschlag, Verdunstung, Abfluss und Gletscherspende im Gesamtgebiet der Alpen im Jahresdurchschnitt für die Normalperiode 1931-1960. Oldernburg, Munich.

Bavay, M., M. Lehning, T. Jonas and H. Löwe. 2009. Simulations of future snow cover and discharge in Alpine headwater catchments. Hydrol. Process., 23(1), 95-108.

Bavera, D. and C. De Michele. 2009. Snow water equivalent estimation in the Mallero basin using snow gauge data and MODIS images and fieldwork validation. Hydrol. Process., 23(14), 1961-1972.

Blanchet, J., C. Marty and M. Lehning. 2009. Extreme value statistics of snowfall in the Swiss Alpine region. Water Resour. Res., 45(W5), W05424. (10.1029/2009WR007916.)

Daly, C., R.P. Neilson and D.L. Phillips. 1994. A statisticaltopographic model for mapping climatological precipitation over mountainous terrain. J. Appl. Meteorol., 33(2), 140-158.

Foppa, N., A. Stoffel and R. Meister. 2005. Snow depth mapping in the Alps: merging of in situ and remotely-sensed data. EARSeL eProc., 4(1), 119-129.

Gauer, P. 2001. Numerical modeling of blowing and drifting snow in Alpine terrain. J. Glaciol., 47(156), 97-110.

Grünewald, T., M. Schirmer, R. Mott and M. Lehning. 2010. Spatial and temporal variability of snow depth and ablation rates in a small mountain catchment. Cryosphere, 4(2), 215-225.

Jonas, T., C. Marty and J. Magnusson. 2009. Estimating the snow water equivalent from snow depth measurements in the Swiss Alps. J. Hydrol., 378(1-2), 161-167.

Keller, M.M., T. Strobel and F. Forster. 1984. Die räumliche und zeitliche Variabilität der Schneedecke in einem schweizerischen Voralpental. DVWK-Mitt. 7.

Kirchhofer, W. and B. Sevruk. 1992. Mittlere jährliche korrigierte Niederschlagshöhen 1951-1980, Blatt 2.2. In Landeshydrologie und Geologie, ed. Hydrologischer Atlas der Schweiz. Bern, EMDZ-Vertrieb.

Lang, H. 1985. Höhenabhängigkeit der Niederschläge. In Sevruk, B., ed. Der Niederschlag in der Schweiz. Bern, Geographischer Verlag Kümmerly \& Frey, 149-157. (Beiträge zur Geologie der Schweiz - Hydrologie 31.)

Lauscher, F. 1976. Weltweite typen der Höhenabhangigkeit des Niederschlags. Wetter Leben, 28, 80-90.

Lehning, M., P. Bartelt, B. Brown, T. Russi, U. Stöckli and M. Zimmerli. 1999. SNOWPACK model calculations for 
avalanche warning based upon a new network of weather and snow stations. Cold Reg. Sci. Technol., 30(1-3), 145-157.

Lehning, M., H. Löwe, M. Ryser and N. Radeschall. 2008. Inhomogeneous precipitation distribution and snow transport in steep terrain. Water Resour. Res., 44(W7), W07404. (10.1029/2007WR006545.)

Liston, G.E., R.B. Haehnel, M. Sturm, C.A. Hiemstra, S. Berezovskaya and R.D. Tabler. 2007. Simulating complex snow distributions in windy environments using SnowTran-3D. J. Glaciol., 53(181), 241-256.

López-Moreno, J.I. and M. Stähli. 2008. Statistical analysis of the snow cover variability in a subalpine watershed: assessing the role of topography and forest interactions. J. Hydrol., 348(3-4), 379-394.

Mott, R. and M. Lehning. 2010. Meteorological modeling of very high-resolution wind fields and snow deposition for mountains. J. Hydromet., 11(4), 934-949.

Mott, R., M. Schirmer, M. Bavay, T. Grünewald and M. Lehning. 2010. Understanding snow-transport processes shaping the mountain snow-cover. Cryosphere, 4(4), 545-559.

Pipp, M.P. and W.W. Locke. 1998. Local scale variability in storm snowfall and seasonal snowpack distributions in the Bridger Range, Montana. In Troendle, C., ed. Proceedings of the 66th Western Snow Conference, 20-23 April 1998, Snowbird, UT, USA. Fort Collins, CO, Colorado State University, 26-37.

Rohrer, M.B., L.N. Braun and H. Lang. 1994. Long-term records of snow cover water equivalent in the Swiss Alps. 1: Analysis. Nord. Hydrol., 25(1-2), 53-64.

Schirmer, M. and M. Lehning. In press. Persistence in intra-annual snow depth distribution. Part II: fractal analysis of snow depth development. Water Resour. Res.
Schirmer, M., V. Wirz, A. Clifton and M. Lehning. In press. Persistence in intra-annual snow depth distribution. Part I: measurements and topographic control. Water Resour. Res.

Schwarb, M., C. Daly, C. Frei and C. Schär. 2001. Mittlere jährliche Niederschlagshöhen im europäischen Alpenraum 1971-1990, Tafel 2.6. In Landeshydrologie und Geologie, ed. Hydrologischer Atlas der Schweiz. Bern, EMDZ-Vertrieb.

Schweizer, J., J.B. Jamieson and M. Schneebeli. 2003. Snow avalanche formation. Rev. Geophys., 41(4), 1016. (10.1029/ 2002RG000123.)

Sevruk, B. 1997. Regional dependency of precipitation-altitude relationship in the Swiss Alps. Climatic Change, 36 (3-4), 355-369.

Sevruk, B. and K. Mieglitz. 2002. The effect of topography, season and weather situation on daily precipitation gradients in 60 Swiss valleys. Water Sci. Technol., 45(2), 41-48.

Skaloud, J., J. Vallet, K. Keller, G. Veyssière and O. Kölbl. 2006. An eye for landscapes: rapid aerial mapping with handheld sensors. GPS World, 17(5), 26-32.

Vallet, J. and J. Skaloud. 2005. HELIMAP: digital imagerylidar handheld airborne mapping system for natural hazard monitoring. In Proceedings of the 6th Geomatic Week Conference, 819 February 2005, Barcelona, Spain. Barcelona, Cartographic Institute of catalonia, 1-10.

Wastl, C. and G. Zängl. 2008. Analysis of mountain-valley precipitation differences in the Alps. Meteorol. Z., 17(3), 311-321.

Witmer, U. 1986. Erfassung, Bearbeitung und Kartierung von Schneedaten in der Schweiz. Geogr. Bern. G25.)

Zängl, G. 2008. The temperature dependence of small-scale orographic precipitation enhancement. Q. J. R. Meteorol. Soc., 134(634), 1167-1181. 